\title{
Ghosts of other stories: a synthesis of hauntology, crime and space
}

The fashion designer Alexander McQueen's 1992 MA graduation collection was entitled 'Jack the Ripper Stalks His Victims'i. McQueen had long felt drawn towards London's East End, the site of the Ripper murders in the late nineteenth century. He claimed, for example, that a relative had owned an inn frequented by one of the Ripper's victims. One standout piece within this collection is a pink silk satin frock coat with a thorn pattern. As with many of his pieces, there is an implied violence. An image of the coat shows that the pink dye has pooled or has caught the light in such a way that it resembles dried blood. The dummy upon which it rests has red-smeared legs. The thorns resemble a circulation map gone horribly awry. Each of his collections was starkly theatrical, but it is a small detail in this, his earliest collection, that speaks to our discussion here. McQueen would take locks of his own hair and sew them into his clothing. Within the lining, beneath the thorns and the silk, are those threads of hair. McQueen stated that he used the hair to evoke the practice of nineteenth century "prostitutes" selling locks of their hair that could then be given as gifts to lovers. My purpose in referring to it here is to point to stories of crime and violence that are hidden and unseen, but that make their presence felt in curious ways. This particular imprint has been changed and altered in the telling. It evokes an oral tradition of tales of violence and deprivation that are now passed on through a material, yet hidden, form. It is a practice that carries within it threads to traumatic events.

In this article, I set out a means of unpacking how traumatic events are "incorporated" in city spaces. Just as McQueen's frock coat carried within its lining an evocation of past practice, my suggestion here is that spaces can similarly be "haunted" by past traumas. As set out here, a spatio-hauntology of the traumatic provides a powerful new analytical tool. By drawing upon the spatial, this analysis taps into Walkowitz's (1992: 5) reading of the city as a 'dense cultural grid'. This pictures the city as overlapping spheres of 'myth, memory, fantasy and desire' (Parsons, 2000: 1). It speaks to a 'city's collective memory as ghostly trace' (Luckhurst, 2012: 294). Part of the process here then is to access the interplay between place and memory, and how they, in turn, constitute and are constituted by the "strange" edge spaces of late modernity. This is a task of sifting through fragments of text, speech and space. To use Baker's (2012: 284) evocative expression, it is to read an "'echoic" haunting process'.

Criminology has embraced the spatial atmospherics of crime, be it the 'commonplace geographies and the imaginations of everyday actors' (Linnemann, 2015: 514) or etched upon city spaces and offering an 'alternative social geography' (Kindynis, 2017: 513). Trauma studies too has taken a "spatial turn" (cf. Coddington and Micieli-Voutsinas, 2017). My approach here is to synthesize these perspectives in order to unpack the marginal and the vanished, the historical and the myth. This piece then is a response to Linnemann's (2015: 530) call to 'confront these ghosts of past violence and reckon the force of haunting as a social phenomenon'. What follows is a framework to read the spatial traces of trauma.

The structure of this piece takes the following journey. I will initially introduce the concept of hauntology and how it describes the "haunting" of the present by the past. We can then unpack the process of haunting by examining the figure of the ghost (or, more precisely, the 
"phantom" and the "specter"). For this it is useful to examine the processes of introjection and incorporation as described by psychoanalysis as the former details the ways in which the phantom is created within the psyche. So, this section outlines the formation of the phantom, where it resides (namely, a "crypt") and how it reveals itself. The innovation of this article lies in taking these ideas associated with hauntology and transposes them from psychoanalysis and literary criticism to spatial analysis. I describe the ways in which we can co-mingle spatial theory (in particular, that of Lefebvre and de Certeau) with hauntology to "read" spaces that have experienced trauma. Finally, I will be illustrating this idea by referring to a site specific performance piece entitled 'Die Familie Schneider'ii. The artwork, by the conceptual artist Gregor Schneider, was located in London's East End. As I set out, the artwork can be read as a spatial "crypt", containing the "phantom" of traumatic events that have occurred in the surrounding locale. Its utility here - within a criminological context - is that it evokes the "ghosts of past violence" that Linnemann describes.

In addition to discussing Die Familie Schneider towards the end of this article, I will provide brief descriptions of other site-specific artworks. These descriptions are dotted throughout the coming discussion of hauntology, phantoms and crypts. My purpose for these accounts is twofold: firstly, I wish to evoke McQueen's practice of secreting threads within the lining of clothing. So, these will be threads, within, but apart from the main discussion. They are also "buried" within, but apart from the text itself. Yet, they comment upon the arguments that surround them. As such, they will also be illustrative of Derrida's notion of the "supplement"iii. This points to the second reason for including these "threads". They serve to provide examples of the key theoretical points. When we return to Die Familie Schneider, we can see how each of the elements of haunting and the spectral can be "read" within its space. Haunting, as described by psychoanalysis and literary criticism, reveals itself through somatic symptoms or linguistic tics. A spatialised haunting, as I set out here, sees a material transposing of these symptoms. They allow us to trace the presence of the spectral. We will examine Die Familie Schneider to find its phantoms. Before we proceed, let us first consider the meaning of "hauntology" itself.

\section{Hauntology}

As Benjamin (1999: 216) put it, 'space disguises itself - puts on, like an alluring creature, the costumes of moods'. It is our task to see how secret and disguise interpenetrate one another. Hauntology is a powerful means by which to explore this. However, notions of the ghostly and haunting must first be separated from their normative understandings. Haunting as discussed here is not concerned with the validity or otherwise of "ghosts". Rather, it points to the impermanence of the apparently solid foundations of 'the living present' (Jameson, 1999, cited in Davis, 2005: 373). In this sense, the past 'is still very much alive and at work' (Jameson, 1999, cited in Davis, 2005: 373). For Buse and Stott (1999: 11), the 'ghost' sees a collapsing of past and present, as well as, 'anticipations of the future'. They illustrate this with reference to Hamlet and the "return" of the titular character's dead father: the ghost 'arrives from the past in order to make a demand on his son's future' (ibid.,: 14). It is the anticipation and possibilities of the future that we will return to in due course.

Our focus for now lies in how 'a repressed or unresolved social violence' from the past reveals itself in the present (Gordon, 2008, xvi). Haunting is not an abnormal state. It is an everyday phenomenon. Indeed, the act of haunting 'may be a necessary condition of 
possibility for "the present"... to exist' (Frosh, 2013: 41). Haunting undergirds the present. It is in the manner in which the haunting occurs in the background, unseen and unheard except in flashes of revelation, that open up phenomena and institutions to analysis. Rand (1994: 169), for example, sees the value of hauntology in its 'potential to illuminate the genesis of social institutions [as well as] new perspective...into the psychological roots of cultural patterns and political ideology'. We can illustrate this by referring to Frosh's (2013: 54) description of hauntology as the 'precursor of post-colonial studies'. So, this reading would position colonialism as stealing, expunging and overwriting the histories of oppressed groups. The particular social violence or trauma associated with colonialism goes unsaid, yet haunts and spectrally emerges within the history of the colonisers. It is something 'imagined and felt as absent...that continues to haunt the present' (Frosh, 2013: 54). To paraphrase Abraham (1975: 174), the trauma is felt through 'the gaps left within' the colonised.

Thread one: Christian Boltanski's (1990) The Missing House was located in Berlin. More specifically, it was an absence between 15/16 Grosse Hamburger Strasse in East Berlin. On the $3^{\text {rd }}$ February 1945, Allied bombing caused massive structural damage to the house. We might easily infer that some of its inhabitants died in or under the collapsed central stairwell. Subsequent repairs shored up the walls of the housing blocks either side. A gap, an absence of a house-width, was left. In 1990 Boltanski installed plaques on the walls that demarcated the gap. The plaques, positioned at the heights of the various storeys of the property, gave the name, dates of residence and occupation of the residents at the time of the bombing. A lingering absence exists within this absence though. Until 1942, many of the buildings residents were Jewish. By the time of the building's destruction in 1945, those earlier residents would have been 'evicted, displaced, deported, and presumably liquidated' (Solomon-Godeau, 1998: 3). Multiple absences overlap within the gaps between buildings. The haunting occurs in the absence that exists alongside those name plates of the residents from 1945; the plates are "haunted" by the names of those earlier - absent - residents.

\section{Introjection and incorporation}

Before we proceed further, it is useful to focus upon this conceptualisation of the ghost and the practice of haunting within psychoanalysis. It is this reading of the spectral that informed Derrida and underpins the basis of the argument outlined here.

Our starting point is the relationship an individual has with "objects" outside of themselves. These objects can be another individual, a place, community 'or even ... ideals' (Schwab, 2010: 45). The loss of that object to whom or which the individual has an attachment should - if the process is carried out correctly - be managed through a process labeled introjection. It is a gradual process of replacing the object 'out there' with 'one inside' (Castricano, 2001; Rycroft, 1968/1995). What this entails is an internalization of the object - now lost - with an internal mental representation. This movement of the mental representation within the Unconscious allows for the continued growth of the individual. However, there can be a failure or refusal 'to digest or assimilate the other' (Castricano, 2001: 36). Rather than a process of introjection, there is one of incorporation. In contrast with introjection, incorporation is 'fantasmatic, unmediated, instantaneous, magical, sometimes hallucinatory' (Derrida, 1986: xvii). 
Simply put, introjection, or the fashioning of mental representation within the psyche, demonstrates an acceptance that the object "out there" has been lost. Incorporation denies the loss. The object is still brought "within" in incorporation, but as though it was alive. In a Poe-like turn of phrase, Derrida (1986, cited in Castricano, 2001) describes them as 'words buried alive'. The incorporated object - the "ghost" - can then speak through the individual in whose Unconscious they are "buried". In the documentary Ghost Dance (1983, dir. K. McMullen), Derrida explains that 'the ghost is me'. As he states, the ghost 'ventriloquizes' his words. It plays 'his role':

If I'm a ghost, but believe I'm speaking with my own voice...it's precisely because I believe it's my own voice that I allow it to be taken over by another's voice. Not just any other voice, but that of my own ghosts.

(Ghost Dance, 1983)

Abraham (1975: 173) succinctly describes the ventriloquizing phantom as being 'like a stranger within the subject's own mental topography'. This ventriloquizing ghost can be heard in the 'silence, gap, or secret in the speech of someone else [who] "speaks"...through the words and acts (readable as words) of the subject' (Rashkin, 1992: 28). The process of incorporation is done in secret (Torok, 1968: 114). It is hidden 'even from the ego' (Torok, 1968: 114). A structure is then built around the incorporated dead object: a crypt.

Reconstituted from the memories of words, scenes, and affects, the objectal correlative of the loss is buried alive in the crypt as a full-fledged person, complete with its own topography. The crypt also includes the actual or supposed traumas that made introjection impracticable. A whole world of unconscious fantasy is created, one that leads its own separate and concealed existence.

(emphasis added, Abraham and Torok, 1972: 130)

The crypt, 'built by violence', has an eel-like slipperiness to itiv (Derrida, 1986: xv). It is a construct that hides and is itself hidden. It is a secret, even, to the individual in whom it is contained. If the crypt is cracked (as a result of the trauma being broached through psychoanalysis) the phantom is either partially revealed in speech and text or manifest in somatic symptoms. Castricano (2001: 46) has a particularly apposite phrasing for this, seeing 'language as haunted architecture'. The phantom churns within the crypt. It is doomed to endlessly repeat the trauma, the loss, for which it was originally incorporated. It is entombed. It has been "buried alive" and yet awaits resurrection. It is instructive to focus upon the term "crypt" itself to see how that hints at what occurs within this hidden, occulted region. We can think of both the crypt and to crypt. The latter speaks of encryption, of a cipher to be cracked. The former highlights the relationship between the crypt and its contents. A vault keeps its contents safe. A vault can also lockdown its contents in order to keep those outside safe. The contents of the crypt similarly imply something of value, a 'ghostly inheritance' (Castricano, 2001: 9): 'whether in the sense of what is received by descent or succession or what returns in the form of a phantom to tax the living'.

Thread two: Rachel Whiteread's (1993) Untitled (House)v was located at 193 Grove Road, Mile End in London's East End. The piece consisted of three-storeys of a house cast in concrete. Its walls, floors and roof were removed. The space it had contained, its volume, was rendered solid. It was an architectural negative. In Saltzman's (2006) evocative expression, it was the 
building's death mask. In memorialising the building, the home, it spoke to the history of the area: its nineteenth century industrial workers, suffragists, its wartime destruction and midtwentieth century changing demographics. The concrete of Untitled (House) doubled the nearby high-rises, but not the bricks and mortar of the home itself. Untitled (House) took a somewhat different approach, then, to the absence and presencing of spectrality seen in Boltanski's The Missing House. Rather, here was the ghost as imposing physicality. Or, rather, this was not simply a ghost, phantom or specter. Saltzman (2006: 90) points instead to the crypt-like nature of the concrete, carrying within it the 'trauma, through which modern female subjectivity was established, and, in many instances, utterly evacuated and effaced. Like a monument to an unknown soldier, Whiteread's sculpture marks and commemorates those subjects of history who bear no literal trace, who are not so much lost, as lacunae in the archives of modernity'. Within the solidity of the concrete, the crypt contained this trauma of the voiceless and hidden.

Both Derridean specter and Abraham and Torok's phantom - and we will differentiate the two shortly - reveal themselves in similar ways. They emerge through 'gaps in or deformations of language' (Schwab, 2010: 53): 'metaphor, metonymy, homophony, homonymy, puns, semantic ambiguities, malapropisms, anagrams, and rebus and similar figures that all combine concealment and revelation'. The crypt can be unlocked and the phantom exorcized (or specter rendered observable) through an examination of the subject's speech and symptomology.

The differences between Abraham and Torok, and Derrida in their formulation of that which haunts are subtle, but important. For ease, I will follow Davis' (2005) separation into "phantoms" for the former and "specters" for the latter (although, as Davis points out, they were themselves inconsistent on this). For Abraham and Torok, the phantom is a trickster. The traumatic loss that preceded its formation was associated with 'shame and prohibition' (Davis, 2005: 378). Abraham and Torok's "phantom" lies to mislead its host in order to maintain its secret. The secret that the phantom hides needs to be "be put into words so that the phantom and its noxious effects on the living can be exorcized' (David, 2005: 378). This exorcism would not be a simple process. Rather, given Abraham and Torok's psychoanalytic background, the secret would be 'read' and the phantom made 'sayable' through 'multiple, laborious and creative processes of translation or 'analytic-poetic transcription' (del Pilar Blanco and Peeren, 2013: 7).

The Derridean specter, in contrast, is somewhat different. Derrida's (1994) reading is most closely associated with the titular SPECTERS OF MARX. This unpacks the ways in which the opening line of THE Communist MANIFESTo - ' [a] specter is haunting Europe - the specter of communism' - pre-figured Marx's on-going "haunting” of a post-1989 world. This specter requires more of a séance to be teased out than an exorcism to be expelled. The specter does not carry the negative connotations of the Abraham and Torok phantom. This figure does not "lie" to observe its secret or to remain hidden. Rather, as with the "return" of Hamlet's father, it destabilizes the distinction between past and present, and as a result, opens up the future. The specter 'becomes...a figure of clarification with a specifically ethical and political potential' (del Pilar Blanco and Peeren, 2013: 7). A revealed encounter with the specter offers 'a productive opening of meaning' (Davis, 2005: 377). We will return to both phantom and specter in due course, but a central feature of "haunting" - both in psychoanalysis and literary criticism - is the notion that the trauma can be transferred to others. 
As discussed earlier, Frosh (2013) uses this as a means to explore the impact of colonialism: a trauma that was passed down from one generation to the next, its traces readable in the gaps and elisions of language and text used to describe colonial practice. Rashkin (1992: 478) applies this idea to literary 'text[s] in distress'. For example, a poem within Poe's (1839/2003) THE FALL OF THE HOUSE OF USHER reveals the "phantom"/secret/trauma that haunts the main text. In this framework, the text acts as the "crypt" - described above containing and "hiding" the phantom and its traumatic secret. Further, in this analysis, the phantom manifests itself in

thematic, behavioral, and linguistic elements of texts, ranging from obsessions, hallucinations, compulsive repetition, and fetishism to uncanniness, ghosts and haunting, as possible signs or symptoms of unrecognized dramas that perturb a character because they have been concealed by someone in a preceding generation.

(Rashkin, 1992: 156)

So, within this framework, individuals who did not suffer the original trauma themselves can still take within themselves the crypt and its phantom/specter. This transmission is described as transgenerational haunting. It is a means, for example, to describe the posttraumatic symptoms of children of Holocaust survivors. As described thus far, the construction of the crypt follows the failure to successfully introject the love-object. Transgenerational haunting, or the transmission of the crypt (containing a phantom that endlessly repeats the trauma that led to its burial), sees the 'burial of an unspeakable fact within the love-object' (Abraham, 1975: 172), which is then itself passed on to another. Rashkin (1992: 27/28) provides the example of this passing from parent to child:

The unspeakable secret suspended within the adult is transmitted silently to the child in "undigested" form and lodges within his or her mental topography as an unmarked tomb of inaccessible knowledge. Its presence there holds the child (later the adult) in a pathogenic dual union with the parent, in a silent partnership dedicated to preserving the secret intact.

Schwab (2010) expands upon this to argue that the crypt can be passed on inter- and intragenerationally between groups, as well as individually. This can lead to trauma being experienced as a 'collective burial ground' (Schwab, 2010: 22).

\section{A spatialised haunting}

Schwab's collective burial ground speaks to both a spatial, as well as a shared experience of incorporated trauma. Haunting is itself co-constitutive of space. In Mourning and Melancholia, Freud (1917/1984) proposed that a 'melancholic attachment to lost objects' is not limited to loved ones, but can be applied to place as well (Schwab, 2010: 45). Pile (2005: 143) touches upon this by stating that the figure of the 'ghost' embodies 'the heterogeneous temporalities of the city': 'innumerable pasts - tragic, traumatic or otherwise - co-exist' (Pile, 2005: 143). My hauntologically-informed reading is slightly different. Here, those instances of the traumatic are locked away within the space of the present. Or rather, it is within and to the side; it is a supplement that goes unsaid and unseen, yet emerges through spatially somatic symptoms, events and tics. Schwab (2010: 3), in a powerful phrase, 
describes violent histories generating 'psychic deformations passed on from generation to generation across the divide of victims and perpetrators'. Schwab's description here relates to the linguistic transmission of that trauma. My argument is that which occurs linguistically can also occur spatially.

Thread three: Krzysztof Wodiczko's (1998) Bunker Hill Monument Projection was located in Boston, Massachusetts. The Bunker Hill Monument, a 221ft granite obelisk was erected in 1820 to commemorate a battle that took place in 1775 during the American Revolutionary War. In 1998 the artist projected video testimony (with accompanying audio) from local community members onto the monument. Each of the videos recalled the violent deaths of family members. Wodiczko's work can be seen as an attempt to give "voice and visibility" to those who had been silenced and rendered invisible. The phantoms of the trauma are ventriloquized through those voices that echo out across the Monument site. The area surrounding the monument had become one of the most impoverished sites of the city. The resonance of the video testimony came from the co-mingling of visibility and memorialization. The video testimony gave voice to the forgotten victims of the contemporary violence. The trauma of both historical and contemporary violence came together in the same space. The trauma circulating within this collective burial ground was given vivid, visible form as it was overlaid upon the static memorial of the Monument.

What I propose here is an act of transliteration. We can apply hauntology to the spatial. Huyssen (2003: 7), for example, discusses the value of using 'literary techniques of reading historically, intertextually, constructively, and deconstructively' in order to unpack 'our understanding of urban spaces as lived spaces that shape the collective imaginaries'. We can use one of the spatial theorist Henri Lefebvre's (1991) triads of space as frameworks upon which this style of analysis can be carried out. We can tease out how the "haunting" effects of past trauma impacts understandings of space shape the present and hint at future resolution.

A spatial incorporation of trauma can result in a crypt forming that contains a phantom/specter. As we have established, the crypt and its contents are produced through language. As I set out here, the spatial crypt is both linguistic construct and peculiarly spatial phenomena. Its presence is felt both in these tics and spatialised somatic symptoms. I will unpack this further in due course, but it is important first to examine this particular Lefebvrian triad to see how the crypt can be incorporated.

One of the early triads mentioned in Lefebvre's (1991) The Production of SPACE is that of spatial practices, representations of space and spaces of representation. Spatial practices are concerned with systems of production and the time-space routines associated with them (Gregory, 1994). Representations of space refers to the signs, symbols and codes, the 'constellations of power [and] knowledge', that facilitate the 'dominant social order' (Lefebvre, 1991: 403). Spaces of representation are the space of change. They are 'subordinate, peripheral or marginalised' (Soja, 1996: 68). And yet, from this marginal position, they allow for critique. It is the space of critical artistic responses to accepted systems of order. Haunting can occur across each of these three fields. Spatial practice is where social processes accrete. It is a build-up of sediment through repetition. It then 'propounds and presupposes' that spatial practice, as we might perceive Derrida's specter pre-supposing future action (Lefebvre, 1991: 38). Representations of space, which are the 
conditions of and frameworks for the dominant social order, can similarly enfold the crypt within themselves. We might be reminded here of the ways in which hauntology has been applied to histories of colonialism; a dominant colonial narrative can contain within it the phantom of the traumatic histories of the colonised. Finally - and potentially our most obvious point of intervention - are spaces of representation that are linked to social imaginary full of myths and legends laid down through history and embedded in symbolism' (Carney and Miller, 2009: 38). What is required is a drilling down through the layers of social practice and representation to tease out the presence of the crypt and see its effects. It is, likewise, at these points that we can effect a change to "heal" these spatialised traumas. Lefebvre talks about "Moments" that prompt and provoke critical renewal. It is these points that - mediated by "arts and literature" - transcend the rigid, ordered spaces of production and embrace the social imaginary to change and resist. Whilst I would suggest that a spatial introjection can occur across the three spaces that Lefebvre outlined, it is the third, the spaces of representation, which is most open to intervention. How, though, can it be revealed?

My argument here is that movement through space can be read in order to map the unspoken contours of the haunted. Movement reveals the 'shadows and ambiguities' within the time-space routines of spatial practices (de Certeau, 1984: 101). De Certeau's (1984) "pedestrian speech act" is, similarly, something to be traced through space and read. For de Certeau (1984) we "perform" movement through space. Movement carries with it a truth value; it determines the 'necessary, the impossible, the possible or contingent' (de Certeau, 1984: 99). Similarly, there is an epistemological value. As such, our movement, our speech act, imposes a sense of 'the certain, the excluded, the plausible, or the questionable' (ibid.). An individual's journey to work, for example, may at once be 'necessary' and 'certain'; it is both a requirement and a routine activity. Alternatively, the journey that a prison visitor makes may be 'contingent' and 'excluded'; this individual's path may be rendered difficult. The prison might be poorly served by public transport and there could be institutional barriers blocking entry. The reader will recall that Schwab (2010) suggested that the phantom's underlying presence in speech and text can be traced in gaps or deformations through language, be they metaphor, metonymy and the like. We can see these spatio-linguistic features as traces of a spatial haunting. They are the equivalent of the tics or somatic symptoms. So, the edgeland is a synecdoche - a part that stands in for the whole - for other "edge" features of society. These can then be read as tracing the contours of the crypt or the workings of the phantom. Likewise, we can use this to locate the spectral in an absence between houses in a street in East Berlin or within a block of concrete in East London. Of course, the alleyway that is avoided, the parkland bypassed or the "edgeland" that draws attention are, in and of themselves, not necessarily evidence of anything. Rather, through architectonics, we can triangulate across the triad, across the sedimentations of practice and discourse, as well as the differing values of the speech act to piece together the presence - or otherwise - of the crypt.

We are left with something of a challenge when discussing the encryption of trauma in space. Firstly, how do we locate it? Secondly, what form does it take? Thirdly, how do we unlock it? The first point is, perhaps, easiest to resolve. If we take Tuan's (1979) discussion in LANDSCAPES OF FEAR seriously, then all sites at some point will have been touched by violence. In Linnemann's (2015: 530) apposite phrasing, 'the spaces we travel through are alive with ghosts of the dead'. As such, all spaces are possible crypts. That said, not all traumas lead to introjection. So, it is useful to pull focus to the conditions that could first prompt introjection. This takes us to both the second and third point. We have already 
discussed the over-determined nature of city spaces. As Jansson and Lagerkvist (2009: 5) indicate, the collage has become a useful means of comprehending the 'shifting complex entity' that is the postmodern city. Unhelpfully for our purposes, this renders the city a 'largely illegible "text"' that is 'an unfathomable, heterogeneous web of practices and relations' (Jansson and Lagerkvist, 2009: 5). How best to approach something so fluid, so slippery? Murray (2012: 65) talks of the 'echolalic city...that will forever be in debt to its own ghosts'. However, for our purposes, the echoes - to mix my metaphors briefly - cast a seemingly impenetrable fog across the analysis. The competing voices dissolve into noise. The ghostly signal behind the noise, ventriloquizing through select voices, is lost to analysis.

Rather than be overwhelmed by a polyphonic competition of (ventriloquizing) voices, I have narrowed focus to a singular locale. However, as with Campbell (2013: 20), I still hope to reflect Hayward's reading of a "multi-sensual landscape" of criminological spaces.' The answer is to marry the Derridean notion of haunting as a point of departure with Hillman's (2006) appeal to a creative response to help "heal" pathological city spaces. This would envisage the city as the hauntological 'repository of its own past...but, more radically...contain[ing] the dreams of the future that the past itself generated' (Moore, 2016: 91). So, our task is to read city spaces for the shadows, the gaps and elisions of trauma and to fashion that creative response. By examining 'reconstructed memories and cultural myths' we can move toward both acknowledgment of violent pasts and 'restitution and liberatory action' (Frosh, 2013: 60-61).

This takes us, finally, to the darkened terraced houses in Walden Street in the East End of London. Schwab (2010: 2) describes the recall of trauma as emerging through 'the memories of the body and its somatic enactments'. A spatially felt haunting - in the style of Die Familie Schneider - evokes much the same response. It embodies a spatialized history of violence, a violent colonization of a collective and spatialised psyche. It is both exemplar of a failed mourning of violent pasts and social injustices, as well as a cultural artifact suggesting resolution. In the same way in which Rashkin uses the text within The Fall of the House of Usher (a text "in distress") to reveal its secret, we can read Die Familie Schneider (a space "in distress") as a crypt containing a phantom/trauma.

\section{Die Familie Schneider}

Die Familie Schneider consisted of two neighboring terraced houses in London's Whitechapel. Pairs of visitors would split up and explore one of the houses for fifteen minutes. After fifteen minutes, they would "swap" houses and be met with the revelation that each house - including its inhabitants - was exactly replicated in the other house. Yet, opening the front door and moving into the hallway revealed an initial shocking blankness. There were nails (positioned identically in both houses) to hang frames, but there were no pictures, no photos. The signs of living, of dwelling, were absent. The living room similarly revealed no signs, no imprints, of family life other than piles of cigarette butts in an ashtray. Pushing through a beaded curtain into the kitchen revealed a black-clad woman (again, identical in both houses), silently washing dirty crockery. The noise of running water from upstairs drew the visitor up through a dark, wood-paneled stairwell. The shower ran whilst an adult man, hunched, his back to the door, masturbated. The small room opposite was smaller than one would intuit. Similarly, there were no windows, although windows had been visible earlier when looking at the exterior. Between the bed and the wall, sat a small, child-sized figure. Its upper half wrapped in refuse bags. Moving up to the attic space, the 
visitor was met with a child gate and a locked door beyond. Retreating back down through the tight stairwell into the basement, the visitor was hit with the fetor of persistent, longterm damp. A bookshelf could be pushed aside to expose a crawlspace. Opening a final bolted door revealed a stained mattress.

This site specific art project ran for three months in the Autumn/Winter of 2004. James Lingwood - co-director of Artangel, the arts organisation that commissioned the work stated that the artist Gregor Schneider had requested 'two unexceptional identical houses' (personal communication). The "unexceptional" would reveal a troubling and unnerving interior. This is in keeping with Schneider's other work. Racz (2015), for example, describes 'Totes Haus us (Dead House ur)' constructed in the edgelands near the German city Mönchengladbach. The house was 'within an area already becoming a ghost town owing to the poisonous fumes and economic downturn' (Racz, 2015: 99). As with Die Familie Schneider, this project saw domestic space re-configured in disorienting ways. Rooms were made smaller, passage ways became labyrinthine and there was a sense of disassociation from time. Racz (2015: 103) makes the observation that in Die Familie Schneider the idea of the fragmentation of consciousness as opposed to historical unity was evident in the displacement experienced by the visitor between the outside world and the recently entered house'. The 1970s furnishings suggested a house out-of-time. There were few signs of dwelling and yet the house did have observable inhabitants. My argument is that the history of violence and social trauma in the surrounding area inevitably haunted the piece. Walden Street is located on the edges of the nineteenth century Old Nicol St. Rookery, itself fictionalised in Arthur Morrison's 1896 novel A CHILD OF THE JAGo. The rookery was a space of grinding poverty alongside great wealth. In Charles Booth's London poverty maps of the late nineteenth century, the rookery was shaded in black. This indicated that its inhabitants were the 'lowest class. Vicious, semi-criminal'. It is within a mile of each of the Ripper murder sites. It is a short distance from the location of "The battle of Cable Street". In 1936 the British Union of Fascists attempted to march through the then predominantly Jewish area. They were thwarted by an amalgamation of Irish, Communist, Anarchist and Jewish groups. In 1978, Altab Ali, a 25 year old Bangladeshi man was murdered in a racially motivated attack on a street corner a few hundred metres away. A nearby park was named after Ali in 1998. This is a part of the city that has experienced multiple traumas, most frequently associated with social deprivation and division. The violence of everyday spaces - as described by Tuan (1979) - runs through it. It has seen a layering of social violences to create a collective burial ground. This is a space in distress. This is why Die Familie Schneider works as a splintered crypt whose phantom spoke to its visitors. It drew upon the collective imaginary and aesthetic trends of the spaces of representation of the Whitechapel area. If the crypt is an enfolding of the phantom in an endless repetition of the traumatic act, then Die Familie Schneider's inhabitants - wordlessly stuck in their loops in doubled houses - convey this eerily. The multipled and varied traumas of the area are "ventriloquized" through this artwork. The claustrophobia of the bedroom is a synecdoche for the rookeries of the nineteenth century. It is a spatial echo of Booth's blackened stretches of the East End. Its speechless inhabitants too stand for populations that have inhabited these streets for the last century but who have gone unheard. To use de Certeau's terminology, to move through the homes in Walden Street allowed the visitor to make truth or epistemological statements from within the crypt. They were able to perceive and define the possible, contingent or excluded with their own movement. This was a means to interrogate the spatial crypt and its phantom. The child gate in front of an inaccessible roofspace had dark echoes of Stevie Smith's (1942) troubling Croftvi. We can also take this as a spatial malapropism or ambiguity that prompts unease in the visitor. The sense of things being out-of-place (as well 
as out-of-time), suggests a spatial ambiguity that is then repeated in the basement with its sliding bookcases and hidden crawlspaces. Caruth (1995, cited in Coddington and MicieliVoutsinas, 2017) describes trauma as representing a 'history that literally has no place, neither in the past, in which it was not fully experienced, nor in the present, in which its precise images and enactments are not fully understood'. So it is with Die Familie Schneider. It is unmoored from time, but suffers the endless repetitions of its traumas. The repetition of the 15 minute cycle, the doubling, each serve as a flashback. Following Coddington and Micieli-Voutsinas (2017: 52), 'flashbacks often occur in different times and places than the initial traumatic event itself; the traumatized psyche repeats its pain, (re)focusing upon a place - and time - that cannot be located'. This is the phantom stuck, repeating the trauma but in ways that had been transposed and changed in the re-telling.

Die Familie Schneider closed on 23rd December 2004. It exists now as a two channel video presentation at Turner Contemporary on the South coast of England and in grainy digital files online. It has been stripped of its location. The physicality of this crypt has dissipated, but it remains a vital presence. It continues to exist as space of representation. The phantom of past traumas continues to ventriloquize through it. Alternatively, perhaps we can reframe it as a specter coming from the past to make a demand upon the future.

\section{Ghosts within stories}

The title of this article is taken from the documentary Handsworth Songs (dir. J. Akomfrah, 1986). It is a spoken line of dialogue within a non-linear narrative that explores riots that occurred in the UK in the London in the Midlands in 1985. The complete quote is that 'there are no ghosts here, just ghosts of other stories'. I reference it here because it provides a concise illustration of the transgenerational haunting of space. There is a "here" that contains, not simply "ghosts", but the ghosts of other events (in this example, the social violence leading up to the riots). Further, as with McQueen's coat, it evokes the ways in which an aesthetic response to a trauma can itself be "haunted" by it. So, we can try to use the ideas set out here to try to trace the contours of the "ghosts of other stories". To call upon the "threads" that have punctuated the discussion here, the absence of Boltanski's Missing House, for example, reveals the deeper absences of its former Jewish inhabitants. Rachel Whiteread's Untitled (House) can itself be seen as a spatial crypt. The doubling within Die Familie Schneider speaks to the repetitive flashbacks of a traumatized spatial psyche. In Die Familie Schneider there is a sense of a curdled domesticity in a house that is out of time. The fifteen minute repetitions suggest endless looping flashbacks. The traumatized psyche of the house doubles and repeat its trauma. Of course, much has already been written about the ways in which crime and culture intersect. My argument here is to look to that which has been previously occulted or hidden. We can point to examples such as the Bunker Hill Monument projection as counter-monuments that blur the boundaries between traumatic past and audience. A counter-monument can draw upon the memories of the 'disenfranchised, oppressed and bereaved' and bring visibility to those rendered invisible (Gibbons, 2007: 63). It did so in juxtaposition with the static memorialization of the Bunker Hill Monument itself. As Micieli-Voutsinas (2017: 94) puts it, the contrast was with an 'immobile, static manifestation of collective memory within [a] landscap[ed] monumentality'. The original monument had become a place for the earlier memory to stagnate and die. Wodiczko's Projections onto the monument provide us with perhaps the clearest and most explicit aesthetic engagement with the lived experience of crime-related trauma. It brought the specter to life. Past trauma co-mingled with the present to provoke 
future engagement. Rather than a static memorialization, engaging with an artwork-ascrypt encourages us to re-member.

Space then can be marked by the imprints of ghosts and ghostly imprints. Haunting informs our understanding of what was and shapes what will be. As stated earlier, the conceit of this piece - as derived from criminology - is that greater attention should be given to the multifaceted, over-determined nature of space. Following Campbell (2013: 18), there is a need to move beyond conceptions of the urban as 'an inert material backdrop'. Rather, a hauntologically-informed examination of space will look, paradoxically, to a space alive with ghosts. It provides a further toolset to explore the multi-sensual landscape outlined by Hayward (2012). To be clear, there has also already been a "spatial turn" in trauma studies (cf. Coddington and Micieli-Voutsinas, 2017). The invitation in this article is, instead, to fully integrate both Abraham and Torok and Derrida's reading of the ghost within a spatial framework. However, this is just the first step. The more important - and challenging aspect is to use this, paralleling Campbell's (2013) work on affective energy and city spaces, as a means to "heal" spatial trauma once it has been identified. This speaks to the core of hauntology: "[w]e inherit not "what really happened" to the dead but what lives on from that happening' (Brown, 2001, cited in Freccero, 2007: 342).

And so, if we envisage the trauma taking the form of a Derridean specter and less of a $d y b b u k$-like phantom, then space opens up for positive resolution. We must confront spaces in distress that house the collective burial grounds of their traumas. A critical aesthetic response opens the possibility of collective "restitution and liberatory action". A praxiological response can be given shape and location by a spatially-inflected hauntology. Movement through Die Familie Schneider was a movement through a crypt; it prompted an affective engagement with the particular histories of violence of its surroundings. Hauntology then provides a means of understanding the effects of crime in space, as well as a framework to attempt to resolve them. It allows us to hear the ghosts of other stories.

\section{Funding statement}

The author(s) received no financial support for the research, authorship, and/or publication of this article. 


\section{References}

Abraham N (1975) Notes on the phantom: a complement to Freud's metapsychology. In: Rand NT (ed) The Shell and the Kernel vol 1. London: The University of Chicago Press, pp.171-176.

Abraham N and Torok M (1972) Mourning or Melancholia: introjection versus incorporation. In: Rand NT (ed) The Shell and the Kernel vol 1. London: The University of Chicago Press, pp.125-138.

Akomfrah J (1986) Handsworth Songs. Black Audio Film Collective: United Kingdom.

Baker P (2012) Secret city: psychogeography and the end of London. In: Kerr J and Gibson A (eds) London: from Punk to Blair (2 ${ }^{\text {nd }}$ ed). London: Reaktion Books Ltd, pp.277-291.

Benjamin W (1999) The Arcades Project. Cambridge, Massachusetts: The Belknap Press of Harvard University Press.

Buse P and Stott A (1999) Introduction: a future for haunting. In: P Buse and A Stott (eds) Ghosts: deconstruction, psychoanalysis, history. Basingstoke: Macmillan Press Ltd, pp. 1-20.

Campbell E (2013) Transgression, affect and performance: choreographing a politics of urban space. British Journal of Crimnology 53(1): 18-40.

Carney P and Miller V (2009) Vague spaces. In: Jansson A and Lagerkvist A (eds) Strange Spaces: Explorations into Mediated Obscurity. Farnham: Ashgate Publishing, pp.33-56.

Castricano J (2001) Cryptomimesis. London: McGill-Queen’s University Press.

Coddington K and Micieli-Voutsinas J (2017) On trauma, geography and mobility: towards geographies of trauma. Emotion, Space and Society 24: 52-56.

Danielewski M (2000) House of Leaves. New York: Random House.

Davis C (2005) État Présent: hauntology, spectres and phantoms. French Studies LIX(3): 373-379.

de Certeau M (1984) The Practice of Everyday Life. London: University of California Press.

Del Pilar Blanco M and Peeren E (2013) Introduction: conceptualizing spectralities. In: Del Pilar Blanco M and Peeren E (eds) The Spectralities Reader: ghosts and haunting in contemporary cultural theory. London: Bloomsbury.

Derrida J (1986) Foreword: Fors: The Anglish Words of Nicolas Abraham and Maria Torok (trans B Johnson). In: Abraham N and Torok M The Wolf Man's Magic Word. Minneapolis: University of Minnesota Press, pp.xi-xlviii.

Derrida J (1994) Specters of Marx. London: Routledge. 
Freccero C (2007) Queer spectrality: haunting the past. In: M Del Pilar Blanco and E Peeren (eds) The Spectralities Reader: ghosts and haunting in contemporary cultural theory. London: Bloomsbury, pp.335-359.

Freud S (1917/1984) On metapsychology: the theory of psychoanalysis : 'Beyond the pleasure principle, ' 'The ego and the id' and other works. Harmondsworth, Penguin.

Frosh S (2013) Hauntings: psychoanalysis and ghostly transmissions. Basingstoke: Palgrave Macmillan.

Gibbons J (2007) Contemporary Art and Memory: images of recollection and rememberance. London: I.B.Tauris.

Gordon AF (2008) Ghostly Matters: haunting and the sociological imagination. Basingstoke: Palgrave Macmillan.

Hayward K (2012) Five spaces of cultural criminology. British Journal of Criminology 52 (3): 441-462.

Hillman J (2006) City and Soul. Connecticut: Spring Publications Inc..

Huyssen A (2003) Present Pasts: urban palimpsests and the politics of memory. United States: Stanford University Press.

Jansson A and Lagerkvist A (2009) What is strange about strange spaces? In: Jansson A amd Lagerkvist A (eds) Strange Spaces: explorations into mediated obscurity. Farnham: Ashgate Publishing, pp.1-25.

Kindynis T (2017) Bomb Alert: Graffiti Writing and Urban Space in London. British Journal of Criminology 58(3): 511-528.

Lefebvre H (1991) The Production of Space (trans. D. Nicholson-Smith). Oxford: Blackwell.

Linnemann T (2015) Capote's ghosts: violence, media and the spectre of suspicion. British Journal of Criminology 55(3): 514-533.

Luckhurst R (2012) Occult London. In: Kerr J and Gibson A (eds) London: from Punk to Blair ( $2^{\text {nd }}$ ed). London: Reaktion Books Ltd, pp.292-300.

McMullen K (1983) Ghost Dance. Cornerstone Media: United States.

Micieli-Voutsinas J (2017) An abstract presence: affective heritage at the National September $11^{\text {th }}$ Memorial \& Museum. Emotion, Space and Society 24: 93-104.

Moore B (2016) Ruptures in the city: retrospective memory in Benjamin's Paris and Koolhaas's New York. In: Huskinson L (ed) The Urban Uncanny: a collection of interdisciplinary studies. London: Routledge, pp.90-106.

Morrison A (1896) A Child of the Jago. London: Methuen. 
Murray A (2012) This light was pale and ghostly: Stewart Home, horror and the gothic destruction of 'London'. In: Phillips L and Witchard A (eds) London Gothic: place, space and the gothic imagination. London: Continuum, pp.65-79.

Parsons DL (2000) Streetwalking the Metropolis: women, the city and modernity. Oxford: OUP.

Pile S (2005) Real Cities: modernity, space and the phantasmagorias of city life. London: Sage.

Poe EA (1839/2003). The Fall of the House of Usher and other writings: poems, tales, essays, and reviews. London, Penguin.

Rand NT (1994) Secrets and posterity: the theory of the transgenerational phantom. In Rand NT (ed) The Shell and the Kernel vol 1. London: The University of Chicago Press, pp.165-169.

Rashkin E (1992) Family Secrets and the Psychoanalysis of Narrative. Princeton: Princeton University Press.

Royle N (2003) Jacques Derrida. London: Routledge.

Rycroft C (1968/1995) A Critical Dictionary of Psychoanalysis. London: Penguin Books.

Saltzman L (2006) When Memory Speaks: a monument bears witness. In: L Saltzman and E Rosenberg (eds.) Trauma and Visuality in Modernity. London: Dartmouth College Press, pp.82-100.

Schwab G (2010) Haunting Legacies: violent histories and transgenerational trauma. New York: Columbia University Press.

Smith S (1942) Mother, What is Man? London: Jonathan Cape.

Soja EW (1996) Thirdspace: journeys to Los Angeles and other real-and-imagined places. Oxford: Blackwell Publishers Ltd.

Solomon-Godeau A (1998) Mourning or melancholia: Christian Boltanski's Missing House. Oxford Art Journal 21 (2):1-20.

Torok M (1968) The illness of mourning and the fantasy of the exquisite corpse. In: Rand NT (ed) The Shell and the Kernel vol 1. London: The University of Chicago Press, pp.107-124.

Tuan Y (1979) Landscapes of Fear. New York: Pantheon Books.

Walkowitz JR (1992) City of Dreadful Delight: narratives of sexual danger in late Victorian London. Chicago: The University of Chicago Press. 
${ }^{\mathrm{i}}$ Viewable at http://blog.metmuseum.org/alexandermcqueen/coat-jack-the-ripper/

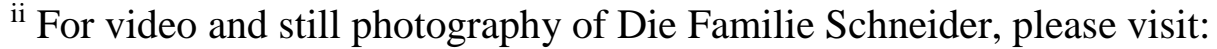
https://www.artangel.org.uk/project/die-familie-schneider/

iii I have also taken my cue here from ergodic literature, such as Danielewski's (2000)

HoUSE OF LEAVES. The intended effect is not to obscure the description of the artworks, nor their relation to hauntology. Rather, the slight disorientation that the reader experiences from the threads appearing within and yet set apart from the text (both on the page and within the narrative flow of the article) is intended to replicate the "maddening" effect of Derrida's supplement (see endnote iv). Likewise, it fulfils a parallel function to Rashkin's (1992) use of a poem within THE FALL OF THE HOUSE OF USHER to tease out the role of the spectral in the main body of the text.

iv Derrida envisages the crypt as of a piece with his wider conceptual category of the supplement. The supplement is both/and/neither inside/outside. Derrida (1967, cited in Royle, 2003: 48) called it 'maddening': 'because it is neither presence nor absence' (cited by Royle). For Derrida, the crypt takes up place within, but outside the ego. This is the meaning of the supplement. Using a spatial metaphor, Derrida (1986: xiv) went onto envisage the crypt as resting out/with/in an 'open square' or a 'forum'. Both suggest a free flow of thought and discourse. Yet, the crypt is a second forum, akin to a 'closed rostrum or speaker's box' but one that is sealed off from its surroundings (Derrida, 1986: xiv). This secret forum or spatial cleft is hidden from the wider forum: a 'secret interior' yet 'outside it, external to the interior' (Derrida, 1986: xiv). It is 'comprehended within another but rigorously separate from it' (Derrida, 1986: xiv). They mask themselves. This is an "artificial unconscious" within the unconscious. It is within their most interior interiority, yet also separate from the ego.

${ }^{v}$ For video and still photography of Untitled (House), please visit:

https://www.artangel.org.uk/project/house/

vi 'Aloft, In the loft, Sits Croft; He is soft.' Smith (1942) 